\title{
Tarihi ve Kültürel Özellikleri İçeren Bir Çevrede Gerçekleşen Teknik Gezilerin İç Mimarlık Öğrencilerinin Kazanımlarına Etkisi: Trabzon Çaykara Bölgesi Örneği
}

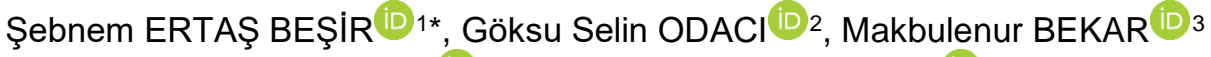 \\ Mikail AÇIKEL iD 4, Mustafa Reşat SÜMERKAN iD 1 \\ ${ }^{1}$ Karadeniz Teknik Üniversitesi, Mimarlık Fakültesi, Trabzon \\ ${ }^{2}$ Avrasya Üniversitesi, Trabzon \\ ${ }^{3}$ Karadeniz Teknik Üniversitesi, Orman Fakültesi, Trabzon \\ ${ }^{2}$ Akdeniz Üniversitesi, Mimarlık Fakültesi, Antalya \\ Geliş Tarihi (Received): 08.04.2020, Kabul Tarihi (Accepted): 17.05.2020 \\ $\square$ Sorumlu Yazar (Corresponding author*): sebnemarc@hotmail.com \\ (C) +904623771608 国 +904623255588
}

\section{ÖZ}

İç mimarlık eğitiminde önemli bir yere sahip olduğu düşünülen teknik gezilerin, hem uygulamalı hem de teorik derslerde yeterli sayıda ve bir program içerisinde gerçekleşmesi gerekmektedir. Diğer bir deyişle, öğrencilerin deneyim kazanmaları uygulama yapmalarına bağlıdır. Böylelikle uygulamalı ve sanatla ilişkili derslerde öğrencilerin yerinde ve yaşayarak bilgileri deneyimlemesi, etkili bir öğrenme sürecine katkı sağlar. Bu doğrultuda yapılan çalışma; teorik anlatıma dayalı olan kültür ve mobilya dersi kapsamında yapılan teknik gezilerin, öğrencilerin öğrenme düzeylerini ve ilgilerini arttırmadaki etkisini ortaya koymak amacıyla çalışma gerçekleşmiştir. Çalışmaya Karadeniz Teknik Üniversitesi mimarlık fakültesi iç mimarlık bölümü ikinci sınıfa devam eden ve gönüllü olarak katılmayı kabul eden 5 'i erkek 20'si kadın 25 öğrenci katılmıştır. Çalışma kapsamında alan gezisi Trabzon'un Çaykara ilçesine bağlı Çambaşı ve Köseli mahallelerine yapılmıştır. Öğrencilere kazanımlarını belirlemek üzere 5'li likert şeklinde hazırlanmış ve motivasyon etkisi, eğitime katkısı, beklenti düzeyi, öğrenme sürecindeki yeri ve yaşanan zorluklar gibi 5 boyutu olan bir anket uygulanmıştır. Çalışma sonucunda elde edilen bulgular, teknik gezilerin, derse olan motivasyonu arttırdığı ve dersteki görsel sunumlardan daha etkili bir öğrenme yöntemi olduğu, bakmak ile görmek arasındaki farkın anlaşıldığı ve mobilya, kültür, tarihi çevre gibi konularına ilgiyi arttırdığı tespit edilmiştir. Katılımcıların benzer uygulamaların tekrar yapılmasını istedikleri ancak hava ve yol koşullarını konusunda olumsuz değerlendirme yaptıkları gözlenmiş, elde edilen bulgular literatür ışığında yorumlanmıştır.

Anahtar Kelimeler: İç mimarlık eğitimi, tarihi ve kültürel çevre, teknik gezi, vernaküler mobilya

\section{Effect of Technical Trips in an Environment Containing Historical and Cul- tural Features on the Achievements of Interior Architecture Students: Case Study of Trabzon Çaykara Region}

\begin{abstract}
Technical trips, which are considered to have an important place in interior design education, should take place in a sufficient number and within a program in both practical and theoretical courses. In other words, it depends on their


experience gaining practice. Thus, in hands-on and art-related lessons, students experience information in place and by living contributes to an effective learning process. In this respect, the study was carried out in order to demonstrate the effect of the technical trips made within the scope of culture and furniture course, which is based on theoretical narrative, on increasing the students ' learning levels and interest. Karadeniz Technical University, Faculty of Architecture, Department of Interior Architecture, 5 male and 20 female students who attended the second year and who agreed to participate voluntarily participated in the study. Technical trip of the study was made in Çambaşı and Köseli neighborhoods of Çaykara District of Trabzon. In order to determine the achievements of the students, a 5-dimensional questionnaire was prepared in the form of a 5-dimensional likert, which has a motivational effect, contribution to education, level of expectation, place in the learning process and difficulties experienced. The results of the study showed that technical trips increase motivation for the lesson and are a more effective learning method than visual presentations in the lesson, that the difference between looking and seeing is understood and that they increase interest in furniture, culture, historical environment. It was observed that participants wanted similar practices to be performed again, but also assessed the weather and road conditions negatively, and the findings were interpreted in the light of the literature.

Keywords: Interior architecture education, historical and cultural environment, technical trips, vernacular furniture

\section{GíRiş}

İç mimarlık kullanıcının estetik kimlik oluşturma beklentilerini karşılamanın yanında işlevsel olarak gereksinimlerine yanıt vererek, en uygun konforlu ortamı oluşturmak için bilimsel ve teknik verileri kullanan tasarım ögelerini içeren bir meslek dalıdır (Berdi Gökhan ve Atasoy, 2005). Diğer meslek alanlarında olduğu gibi bu meslek dalında öğrenim gören bireylerin yetiştirilmesi sırasında onların her anlamda donanımlarını arttıracak farklı öğrenme yöntemlerinin kullanılması bir gereklilik haline gelmiştir.

Öğrencilerin eğitim açısından bireysel intiyaçlarının karşılanması aynı zamanda araştırma yapma, bilimsel metotları kullanma ve eleştirel düşünme gibi birçok davranışı kazanmaları noktasında okulların yanı sıra okul dışı ortamların da her geçen gün önem kazandığı görülmektedir. Öğrenmenin sadece sınıf ortamında olduğunu düşünmek oldukça sınırlılık yaratan bir bakış açısıdır. Eğitim ve öğretim faaliyetleri evde, okulda, işyerinde ve mümkün olan her yerde ve her fırsatta yaşam boyunca devam eden bir sürece dönüşmüştür (Bozdoğan ve ark., 2015).

Eğitimde sürdürülebilirliği sağlamanın en etkin yolu edinilen bilginin birey tarafından deneyimlenmesidir. Bunu sağlamada formal eğitimin yetersiz kalması informal eğitimin gerekliliğini ortaya koymuştur (Sırtkaya Uzun ve Ertaş Beşir, 2019). Bu informal eğitimler, öğrencilerin hem iş hayatında hem de eğitim süreçlerinde başarılı olabilmelerine yardımcı olmaktadır (Camiz, 2014). Bu eğitim türü, öğrencinin gözlem alanı olarak tanımlanırken; okul dışı eğitim okuldaki düzenin değiştiği, başka düzenler, başka ortamlar anlamına gelmekte ve formal eğitimden uzaklaşmayı sağlamaktadır. Bu tür eğitimlerin bir kısmı önceden düzenlenmiş, bir kısmı tamamen spontane olarak ortaya çıkabilmektedir (Yürekli ve Yürekli, 2011). İnformal eğitim programı içinde bulunan "alan gezileri", insanlarda var olan araştırma ve inceleme eğiliminin bir sonucu olarak günümüzde tarih, coğrafya, sosyal bilgiler, sosyoloji, fen bilgisi ve din kültürü gibi eğitimle ilgili birçok alanda çeşitli derslerin öğretiminde kullanılan bir yöntemdir (Mazman, 2007). Birçok bilim adamı, öğrencileri gerçek bağlamlardan öğrenmelerini sağlayan bu tür alan içi öğrenme senaryolarının önemini vurgulamış; öğrencilere problem çözme yetkinliklerini geliştirmede fayda sağladığını belirtmişlerdir (Shih ve ark., 2010). Öğrenciler bu tür gezilerde öncelikle neyi tanıdıklarını ve neyi sevdiklerini ya da aşina olmadıkları şeyleri gözlemlerler. Bu gezide öğrendiklerini yeni ve sıra dışı olarak nitelendirirler.

Öğrencilerin öğrendiklerini ölçmek zordur, bu nedenle çalışmanın öncesinde ve sonrasında beklenti düzeylerinin ölçülmesi önemli görülmektedir.

Bu tür geziler; mühendislik ve mimarlık alanında ise "teknik gezi" olarak ifade edilmektedir. Teknik geziler, ilgili dersin kazanımlarına uygun olarak düzenlendiğinde öğrenme sürecine önemli katkılar sağlayan ve ayrıca ders dışı bir takım becerilerin kazanılmasına yardımcı olan faaliyetler bütünüdür (Sünbül, 2011).

Teknik geziler, öğrenciler için doğal, kültürel ve sosyal öğrenme laboratuvarları olarak düşünülebilir. Bu geziler, bazen sınıfta çalışılan bir konunun pekiştirilmesi için sınıf çalışmalarının sonunda yapılmakta, bazen de bir parçası olarak programın bütünlüğünü sağlayacak şekilde çalışma sırasında gerçekleştirilebilmektedir (Yazıcı, 2013).

Teknik gezi, belli eğitsel amaçları gerçekleştirmek için herhangi bir olayı, önceden hazırlanmış bir plan dâhilinde incelemektir (Ballı, 2009). Ön hazırlık, bilgilendirme, gezi-gözlem, öğrenci sunumları, sunumların değerlendirilmesi olarak aşamalandırılan arazi çalışmalarında; yöntemin seçiminde ortaya çıkan değişkenler 
(dersin içeriği, işlenen konunun özelliği, öğretim elemanının özellikleri ve alışkanlıkları, öğrencilerin özellikleri, öğretim araç ve gereçlerinin durumu) kullanılacak arazi çalışmalarının özelliğini de belirleyen temel faktörlerdir (Çalışkan, 2008). Öğrencilerin; çevreye karşı olan ilgilerini, çevrenin değerlendirilmesi ve sorunların çözümü yönünden duyarlıığını ve toplumun bir üyesi olarak çevreye karşı olan ilgi ve sorumluluğunu arttırması gibi eğitim-öğretimde birçok olumlu etkisi vardır (Atayeter ve Tozkoparan, 2014). Bu anlamda informal eğitimin öğrencilere kısa süreli yaşantıya dayalı eğitim sunması, doğrudan deneyimleme yaşatması, üst düzey motivasyon sağlaması ve öğretimin içeriğini en iyi şekilde kazandırması oldukça önemli bir eğitim modeli olduğunun göstergesidir.

Bir çevreye anlamak için öğrencilerin geziyle ilgili sorumluluklar üstlenmeleri (ön hazırlık, fotoğraf çekme, röportaj yapma, veri toplama gibi) istenebilmektedir. Böylelikle kaynağından bilgi sağladığından, öğrencilere farklı ve somut deneyimler kazandırabilmektedir. Özellikle gezi öncesinde ve gezi sonrasında eğitimciler tarafından öğrencilerin güvenliğinden, her türlü bireysel ihtiyaçlarına kadar ve olası riskler de göz önünde bulundurularak dikkatle planlanarak neler yapılması gerektiğine dair bir yol haritasının çizilmesi önemli bir gereksinimdir.

Teknik gezilerin öğrencilere sunacağı bir diğer kazanım ise, sosyal nitelikli, kaliteli zaman kullanma deneyimidir. Bu yönüyle sosyal, çevreye duyarlı, zamanı etkili bir şekilde yönetebilen, mekâna göre görüş ve davranış geliştiren bireyler yetiştirmeye katkı sağlar (Acar, 2017).

Teknik geziler, ders konularının işlenmesi sırasında, çevredeki kaynaklardan daha çok yararlanılmasına fırsat verebilmektedir. Bu sayede daha fazla duyu organı öğrenme etkinliğine katıldığından ele alınan konu ile ilgili birçok soyut kavram daha iyi öğrenilebilir. (Öner, 2007). Ayrıca bilimsel araştırma ve incelemeyle ilgili bazı temel becerileri de kazanan öğrenciler, iyi bir gözlemci olma fırsatını elde etmiş olurlar. Öğrenciler çevrelerine karşı daha duyarlı davranma eğilimi göstererek bulundukları çevrelerini ayrıntılı bir şekilde tanıyabilirler. Yapılan teknik geziler sonucunda öğrenciler, bir seyahatin nasıl gerçekleşeceği, seyahate çıkarken ve seyahat sırasında nelere dikkat edileceğine dair bilgilerini geliştirme fırsatı bulurlar.

Teknik geziler, olay veya olguların oluştuğu veya halen devam ettiği mekânlara gidilerek gözlem yapmak, yerinde değerlendirmelerde bulunarak olaylar arası ilişkileri tespit etmeyi sağlar (Garipağaoğlu, 2001). Bu da ge- zilerin, sanat ve yaşam ile iç içe olan iç mimarlık öğrencilerine saha çalışmalarının ne kadar farklı kazanımlar katabileceğini göstermektedir.

Özellikle tarihi ve kültürel özellikleri içeren bir çevrede gerçekleşen teknik gezilerin ise öğrencide gözlem yapma ve olaylar arasındaki neden-sonuç ilişkilerini görme yeteneğini geliştirdiği belirtilmişti. Yaşamın farklı dönemlerini tanımaları, öğretim sürecinde hem süreci anlamlı hale getirmekte hem de canlılığı arttırarak ilgi uyandırmakta ve önemli bir kültürel birikim sağlamaktadir.

Çalışmada 2018-2019 eğitim öğretim yılı içerisinde Karadeniz Teknik Üniversitesi iç mimarlık bölümü "Kültür ve Mobilya" dersi kapsamında "Vernaküler Mobilya" tespitine yönelik gerçekleştirilen etkinlikler, iç mimarlık öğrencilerine yapılan anket sonuçlarına göre değerlendirilmiştir. Öğrenciler, bir kültür aracı olan yöresel mobilyaları araştıırken aynı zamanda tarihi ve kültürel özellikleri olan kırsal bir alanı deneyimlemişlerdir. Böylece kültürel ve sosyal açıdan öğrenme düzeylerini ve ilgilerini arttırmada yapılan etkinliklerin ne tür katkılar sağladığı da belirlenmiştir.

\section{Kültür ve Mobilya Dersi Kapsamında Gerçekleştiri- len Teknik Gezi Süreci}

"Kültür ve Mobilya" dersi içeriğini, gezi gözlem metodu çerçevesinde; kültür kavramı, kültür bileşenleri (çevresel imgeler, aile yapısı, yaşam tarzı, dini inançlar) ve bu bileşenlerin mobilyanın biçimlenmesine etkisinin farklı kültürlerde mobilya örnekleri üzerinden incelenmesi oluşturmaktadır. Bu kapsamda 2018-2019 yılı bahar yarılı döneminde; Trabzon Büyük Şehir ve Çaykara Belediyesinin katkılarıyla Trabzon ili kırsal yerleşiminde "Vernaküler Mobilyalar"'ın neler olduğu ve hangi kültürel birikimler sonucu ve ne amaçla kullanıldığının belirlenmesi amacıyla iki farklı alana gezi düzenlenmiştir. Bu süreçte, mobilyalara yönelik önemli envanter çalışmasının yapılmasının yanı sıra alan çalışmasının öğrenme isteklerini ve düzeyini de etkilediği öğrencilere farklı birikimlerde kazandırdığı tespit edilmiştir.

Bu doğrultuda ders sürecinde; Trabzon Çaykara ilçesinde yapılan araştırma sonucunda mobilya envanterine sahip Köseli ve Çambaşı mahalleleri (köyleri) tespit edilmiştir. Çalışma alanında mobilyaların kimlik kartlarının oluşturulması ve arşivlenmesi amacıyla öncelikle oryantasyon, sonrasında ise iki farklı günü kapsayan alan çaıışması sürecine yönelik bir program yapılmıştır (Şekil 1). 


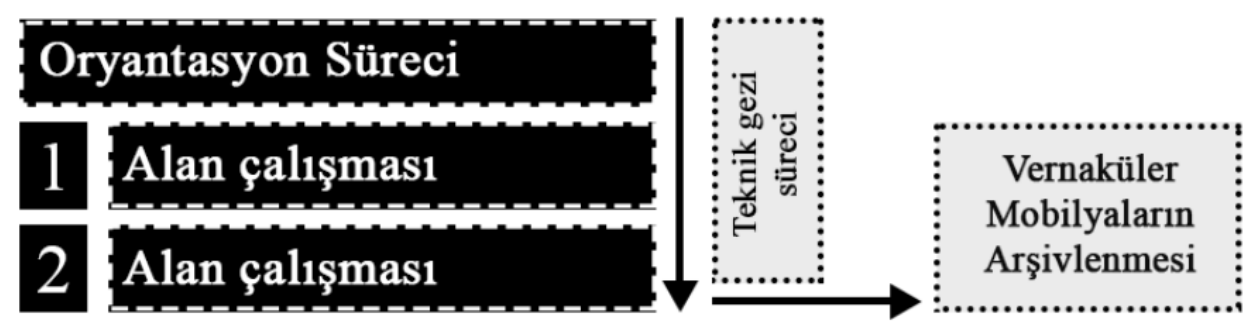

Şekil. 1. Kültür ve Mobilya dersi süreci

Oryantasyon aşamasında; öğrencilere kırsal yerleşmeleri tanımaları amacıyla, seçilen köylerin geleneksel yaşam ve konut kültürü hakkında bilgiler verilmiştir. Alan çalışmasında ise; köylere tüm gün olmak kaydıyla birer gün gezi düzenlenmiş ve iki, üç ve dört kişilik gruplar halinde çalışan öğrencilerden köydeki konutları gezerek kültür aracı olduklarını düşündükleri mobilyalara ait verileri toplamaları istenmiştir. Bu amaçla öğrencilerden fotoğraf çekmeleri, mobilyaların rölövelerini almaları ve öğretim üyeleri tarafından hazırlanan kimlik kartlarına ait verileri mobilyanın sahipleri ile görüşerek doldurmaları beklenmiştir (Şekil 2).

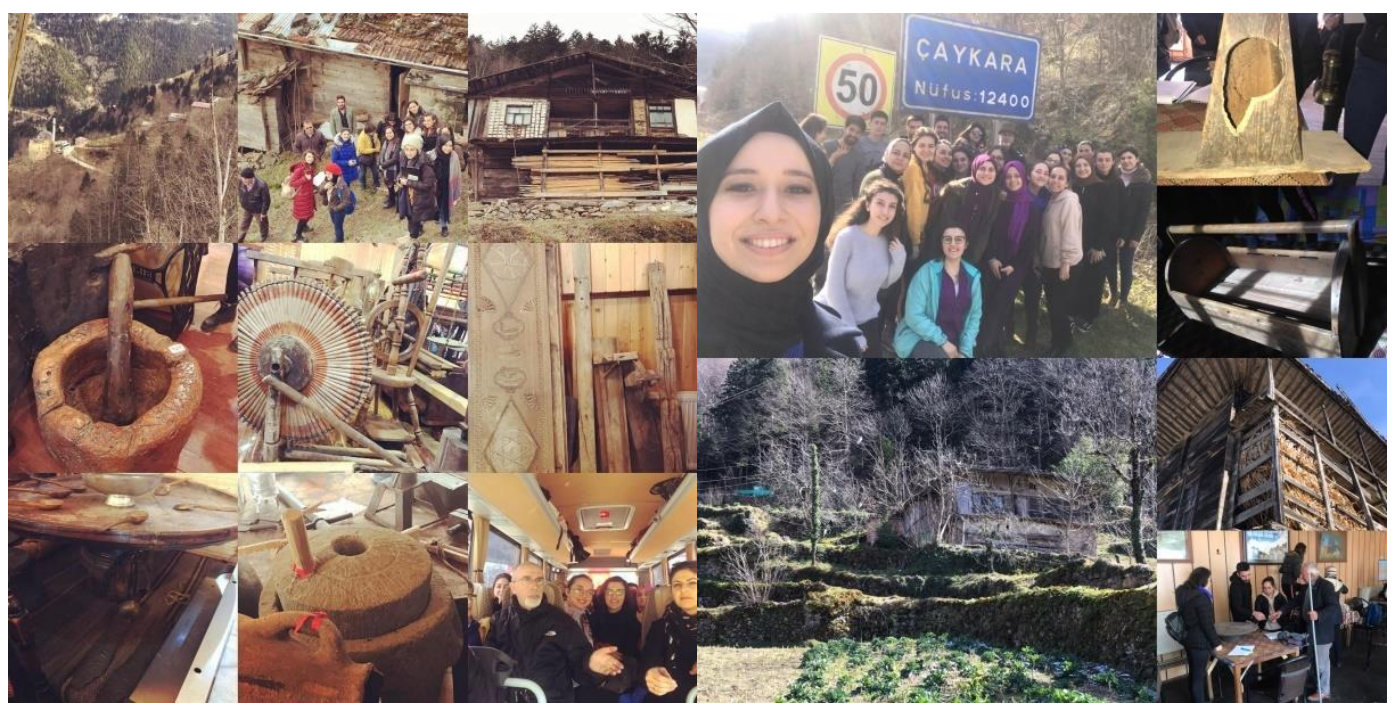

Şekil. 2. 1. ve 2. Alan çalışması (Ertaş Beşir, 2020)

Her gezi sonrası gerçekleştirilen derslerden elde edilen veriler, çalışmaya katılan öğretim üyeleri tarafından değerlendirilmiş ve mobilyanın fiziksel özelliklerine ait bilgileri, fotoğrafları ve ölçülü çizimleri içeren 20 pafta hazırlanmıştır. Bu paftalarda ayrıca mobilya sahibi ve geçmiş dönem kullanımı hakkında bilgide yer almaktadır (Şekil $3)$.

"Kültür ve Mobilya" dersi kapsamında gerçekleştirilen teknik gezi etkinliğinin her bir adımında, öğrenciler farklı deneyimler kazanmışlardır. Bu bağlamda uygulamalı teknik gezilerin öğrencilere sonuç ürünleri oluşturulurken, alanı hem gözlemlemiş hem de teorik ve pratikteki bilgilerini pekiştirmeleri noktasında önemli deneyimler kazandırdığı görülmüştür. Bu süreç teknik gezilerde hazırlanan programın öğrenciler açısından ele alınması gerektiğini ve öğrenci görüşlerine dayanan öneriler ile güçlendirilebileceğini göstermiştir. 


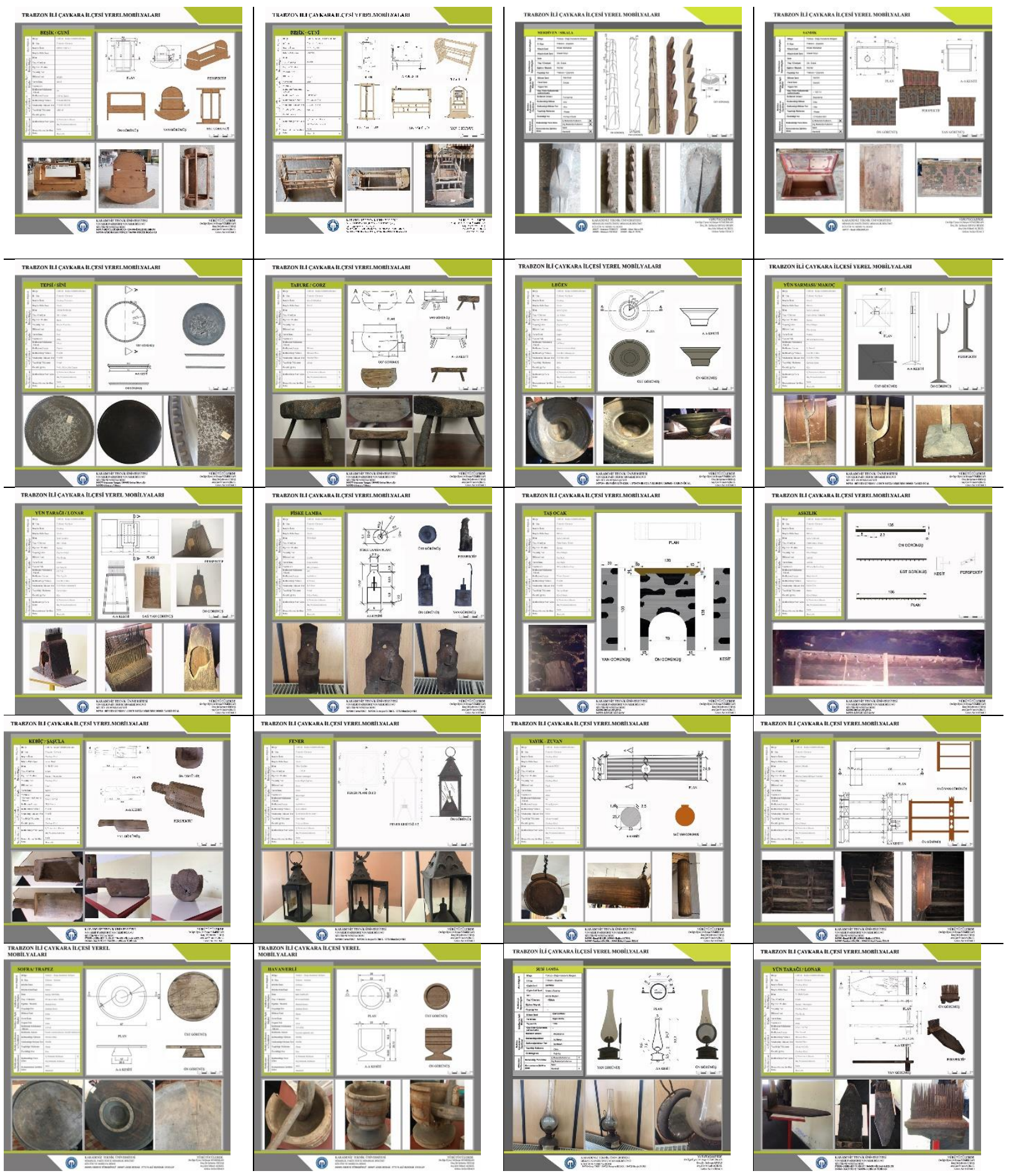

Şekil 3. Alan çalışması sonucu ortaya çıkan ürünler (Ertaş Beşir, 2020)

\section{MATERYAL VE YÖNTEM}

Çalışma; öğrencilerin teknik gezi süreci sonrasındaki deneyimlerinin altı bölümden oluşan anket çalışmasıyla ölçüldüğü nicel tarama yöntemine göre yapılmıştır. İlk bölüm katılımcı profilini (1), ikinci bölüm yapılan etkinliğin katılımcılara sağladığı motivasyon düzeyi ölçümünü (2), üçüncü bölüm çalışmanın iç mimarlık eğitimine katkısını (3), dördüncü bölüm öğrencilerin çalışmanın öncesinde ve sonrasında beklenti düzeylerinin ölçülmesini (4), beşinci bölüm gezilerin öğrenme sürecindeki yerini (5), son bölüm ise alan çalışması sırasında yaşanan zorluklarını ölçmeye (6) yönelik hazırlanmıştır. Çalışmada belirlenen bu bölümlere dair anket soruları Mazman (2007), Yazıcı 
(2013) ve Yüksel (2018)'in yaptığı çalışmalar değerlendirilerek oluşturulmuştur.

Anket çalışması içeriğinde "Likert Tutum Skalası" ölçeği kullanılmıştır. Belirlenen 23 parametre katılımcıların anlayabileceği 23 soruya dönüştürülerek sorgulanmıştır. Parametrelere dair sorular 5'li olup 'Kesinlikle katılıyorum', 'Katılıyorum', 'Fikrim yok', 'Katılmıyorum', 'Kesinlikle katılmıyorum' değerlendirmelerini içerir (Tablo 1).
Yapılan geziye dair kazanımlar "Motivasyon Etkisi", "Eğitime Katkısı", "Beklenti Düzeyi" "Öğrenme Sürecindeki Yeri" ve "Yaşanan zorluklar" başlıklarına göre 5 ana grup altında toplanmıştır. Bu gruplar altında sıralanan ifadelerle değerlendirilme yapılmıştır. Öğrencilere teknik geziye dair kazanımlarını sorgulamak amacıyla "Motivasyon Etkisi" parametresine dair beş soruya yer verilmiştir. "eğitime katkı" 4, "beklenti düzeyleri" 7 ve "öğrenme süreci" parametresi 3, "yaşanan zorluklar" ile ilgili 4 soruya yer verilmiştir (Tablo 1).

Tablo 1. Öğrenci kazanımlarının sorgulayan Likert Tutum Ölçeği

\begin{tabular}{|c|c|c|c|c|c|c|}
\hline & & - & & 0 & & + \\
\hline & Kazanımlar & 1 & 2 & 3 & 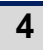 & 5 \\
\hline & $\begin{array}{l}\text { Alan çalışmasına katılmadan önce yapılan bilgilendirme eğitimi } \\
\text { motivasyonumu sağladı }\end{array}$ & & & & & \\
\hline 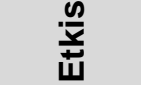 & $\begin{array}{l}\text { Alan çalışması sırasında gezilen müze etkinliği motivasyonumu } \\
\text { sağladı }\end{array}$ & & & & & \\
\hline হ & $\begin{array}{l}\text { Alan çalışması sırasında alanı tanıyan uzman bir öğretim üyesinin } \\
\text { bulunması motivasyonumu sağladı }\end{array}$ & & & & & \\
\hline 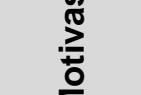 & $\begin{array}{l}\text { Alan çalışması sırasında kırsal konutların gezilmesi motivasyo- } \\
\text { numu sağladı }\end{array}$ & & & & & \\
\hline & $\begin{array}{l}\text { Alan çalışması sırasında yapılan yolculuklar motivasyonumu sağ- } \\
\text { ladı }\end{array}$ & & & & & \\
\hline & $\begin{array}{l}\text { Yapılan bu alan çalışması derse ait bilginin kalıcı olmasına katkı } \\
\text { sağladı }\end{array}$ & & & & & \\
\hline $\bar{\Phi} \bar{g}$ & Yapılan bu alan çalışması dersin teorik bilgisine katkı sağladı & & & & & \\
\hline$\underline{x}$ & Yapılan bu alan çalışması dersin uygulama sürecine katkı sağladı & & & & & \\
\hline & Yapılan bu alan çalışması dersin görsel öğrenme katkı sağladı & & & & & \\
\hline & $\begin{array}{l}\text { Alan çalışmasına katılmadan önce yapılan bilgilendirme eğitimi } \\
\text { beklentimi karşıladı }\end{array}$ & & & & & \\
\hline & $\begin{array}{l}\text { Alan çalışması gezdiğimiz bölgenin kültürünü öğrenme açısından } \\
\text { beklentimi karşıladı }\end{array}$ & & & & & \\
\hline$\stackrel{\mathbb{N}}{\stackrel{N}{2}}$ & $\begin{array}{l}\text { Alan çalışması dönem mobilyalarını ve eşyalarını öğrenme açısın- } \\
\text { dan beklentimi karşıladı }\end{array}$ & & & & & \\
\hline 㟦 & Alan gezisi yapılan bölgedeki halkın tutumu beklentimi karşıladı & & & & & \\
\hline$\frac{0}{\frac{0}{d}}$ & $\begin{array}{l}\text { Alan gezisi yapılan bölgedeki yetkililerin tutumu beklentimi karşı- } \\
\text { ladı }\end{array}$ & & & & & \\
\hline & Alan gezisinin teknik şartları beklentimi karşıladı & & & & & \\
\hline & $\begin{array}{l}\text { Alan çalışması sırasında geziye eşlik eden öğretim üyelerinin yap- } \\
\text { tıkları bilgilendirmeler beklentinizi karşıladı }\end{array}$ & & & & & \\
\hline & Alan çalışması ilgili dersin içeriğine yönelik motivasyonumu artırdı & & & & & \\
\hline 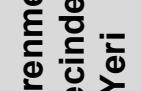 & $\begin{array}{l}\text { Alan çalışması ilgili derse aktif katılım göstermeniz açısından moti- } \\
\text { vasyonumu arttırdı }\end{array}$ & & & & & \\
\hline :०ి: & $\begin{array}{l}\text { Alan çalışması ilgili derse ait sonuç ürünlerini hazırlarken motivas- } \\
\text { yonumu arttırdı }\end{array}$ & & & & & \\
\hline & Alan çalışması sırasında hava koşulları çalışmamı zorladı & & & & & \\
\hline$\stackrel{\frac{\pi}{2}}{\frac{\pi}{5}}$ & Alan çalışması sırasında yol koşulları çalışmamı zorladı & & & & & \\
\hline $\operatorname{m}_{0}^{2}$ & Alan çalışması sırasında yeme-içme koşulları çalışmamı zorladı & & & & & \\
\hline & Alan çalışması sırasında diğer koşullar çalışmamı zorladı & & & & & \\
\hline
\end{tabular}


Çalışmanın istatistiksel çözümünde faktör analizi, korelasyon analizi ve frekans dağılımları incelenmiştir (Tablo 3-4-5-6). Faktör analizi, çalışmanın öğrenciler üzerindeki en etkin faktörleri belirlemek için yapılmıştır. Birçok değişkenin birkaç grupta toplanıp yorumlanmasına imkân sağlayan bu analiz belirlenen 5 başlığa dair en belirgin parametrelerin ortaya çıkmasında yardımcı olmuştur. Bu parametreler ile ilişkili olan ifadeler ise faktör analizinde en çok kullanılan Varimax rotasyonu ile gruplandırılmıştır.

\section{Uygulama Ortamı}

Araştırmanın uygulama ortamını Trabzon ili Çaykara ilçesinde bulunan; yöreye ait birçok mobilya ve eşyanın bulunduğu Çambaşı ve Köseli mahalleri oluşturmaktadır. Alan seçimi için yakın çevrede yer alan birçok muhtarlıkla görüşülmüş ve seçilen mahalleler bu çalışma için önerilmiştir.

Çambaşı, Çaykara ilçemize $7 \mathrm{~km}$ mesafede yer alan bir mahalledir. Köy ismini mahallenin alt kısmında yer alan 3 çam ağacından aldığı bilinmektedir. Çambaşının eski ismi Anoso olup yöresel anlamda Yukarı Köy anlamına gelmektedir. Çambaşında 460 konut yer almaktadır ve günümüzdeki nüfusu ise 578'dir (Şekil 4) (URL-1, 2019).
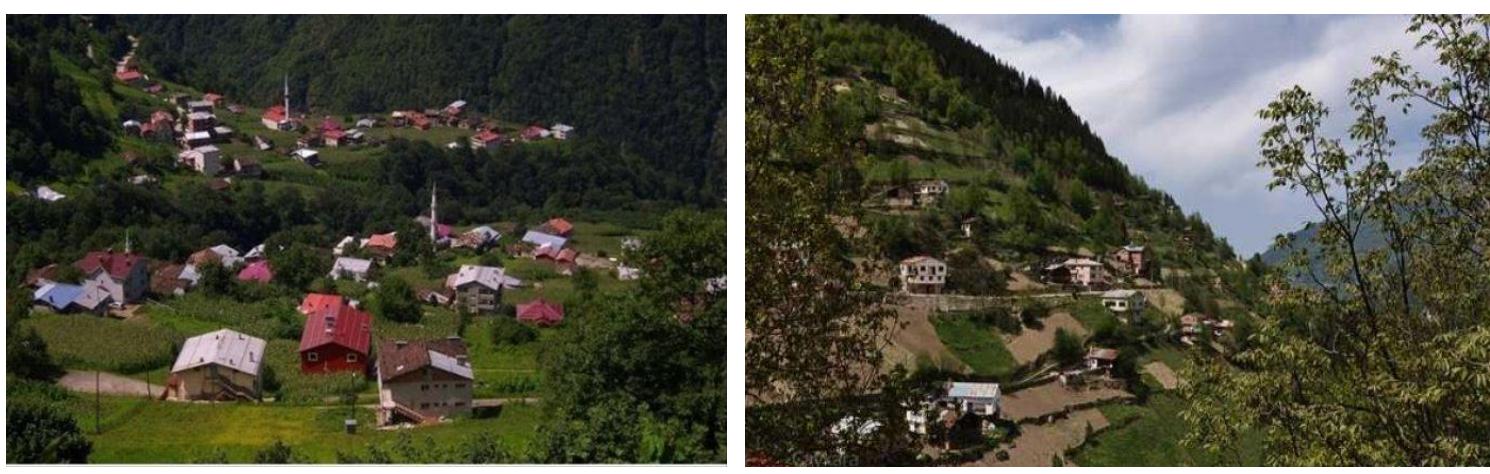

Şekil 4. Çambaşı ve Köseli mahalleleri (URL-1, 2019; URL-2, 2019)

Köseli köyü; İlçe merkezine uzaklığı 17 km'dir. 2000 yılı nüfus sayımına göre nüfusu 239 iken 2014 yılında ise

208'e gerilemiştir. Solaklı Vadisinden güneye doğru ilerlerken vadinin batı yakasında yer almaktadır (Şekil 5) (URL-2, 2019).
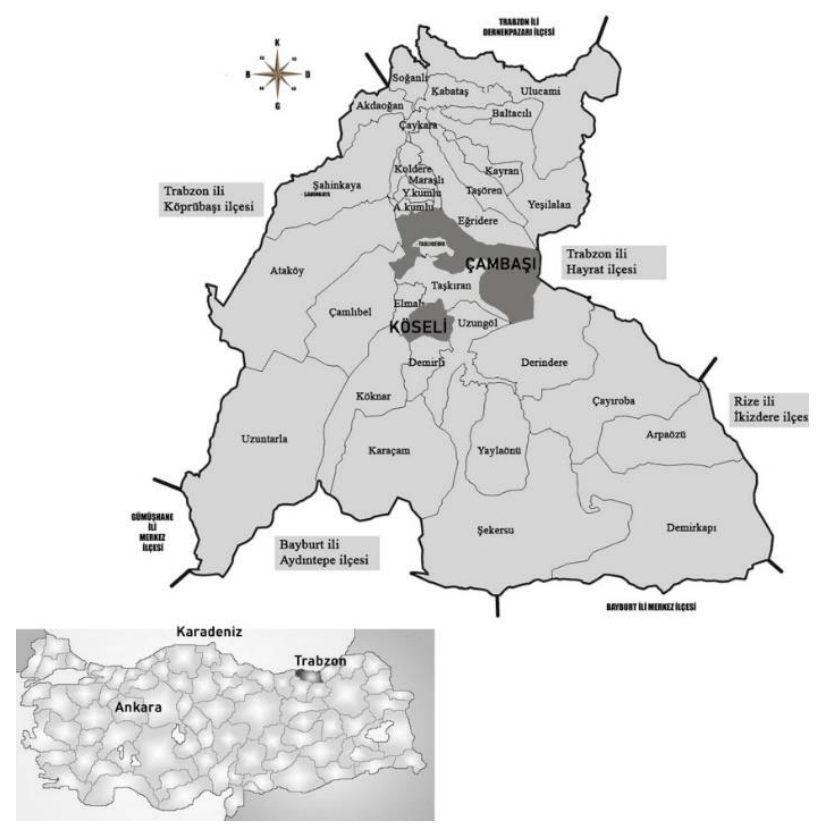

Şekil.5. Çaykara ilçesi, Çambaşı ve Köseli mahallesi (URL-2, 2019) 
Çalışmada 23 Şubat 2019 tarihinde ilk gezi, Çambaşı mahallesine yapılmış; birçok konuta girilmiş özellikle köy muhtarının dedesine ait birçok mobilya tespit edilmiştir. Sonrasında 9 Mart 2019 tarihinde ikinci gezi ise Köseli köyüne düzenlenmiştir. Burada köy muhtarının bir süredir mahallede yaşayan insanlardan topladığı mobilyaları biriktirdiği öğrenilmiştir. Köy içerisinde yapılan araştırmada köy muhtarı tarafından toplanan mobilyalar dışında yöresel bir mobilyanın bulunamaması nedeniyle sadece muhtarın topladığı mobilyalar ele alınmıştır. Böylelikle alan çalışmasında öğrenciler, birçok kırsal konutu ziyaret etmiş; yerinde incelemeler ve arşiv çalışmaları yaparak yaşama kültürünü yerinde incelemiştir.

\section{Çalışma Grubu}

Araştırmanın çalışma grubunu Karadeniz Teknik Üniversitesi İç mimarlık bölümü 2. Sınıf öğrencileri oluşturmaktadır. 2018-2019 bahar yarıyılında Kültür ve Mobilya dersini alan toplam 20 öğrenci ile "teknik gezi" kapsamında Trabzon ili Çaykara ilçesine 2 kez olmak üzere teknik gezi düzenlenmiştir. Çalışmaya katılan katılımcıların \%44'ü 15-20, \%56'sı 20-25 yaş grubu arasındadır. Katılımcıların \%20'si bay, \%80'i bayandır. Kullanıcıların \%16'sı daha önceden böyle bir alan çalışmasına katılmışken \%84'ü ise böyle bir çalışmada daha önce bulunmamıştır (Tablo 2).

Tablo 2. Katılımcıların sosyo-demografik durum analizi

\begin{tabular}{lrrr}
\hline Parametreler & Değişkenler & Sıklık & $\%$ \\
\hline & $15-20$ & 11 & 44 \\
\cline { 2 - 3 } Yaş & $20-25$ & 14 & 56 \\
\cline { 2 - 3 } & $25-30$ & 0 & 0 \\
\cline { 2 - 3 } & $30-35$ & 0 & 0 \\
\cline { 2 - 3 } & $35-40$ & 0 & 0 \\
\cline { 2 - 4 } Cinsiyet & +40 & 0 & 0 \\
\cline { 2 - 4 } & Toplam & 25 & 100 \\
\hline \multirow{2}{*}{$\begin{array}{l}\text { Daha önce hiç alan } \\
\text { çalışmasına katıldınız mı }\end{array}$} & Bay & 20 \\
\hline
\end{tabular}

\section{BULGULAR VE TARTIŞMA}

Yapılan çalışma kapsamında öğrenci kazanımları; Tablo 1 'de verilen 5 başlığa (motivasyon etkisi, eğitime katkı, beklenti düzeyleri, öğrenme süreci, yaşanan zorluklar) göre incelenmiş ve bulgular elde edilmiştir.

Bu doğrultuda; Tablo 3'te yapılan etkinliğin iç mimarlık eğitimine olan katkısını ölçen 6 faktör ve her bir değişkenin faktörler altındaki ağırlıkları verilmiştir. Sonuçlara göre 1. faktör toplam varyansın \% 71,563'ünü oluşturmaktadır. Sonuçlar bu faktör grubu (Motivasyon Etkisi ve öğrenme sürecindeki yeri) altındaki ifadelerin diğer gruplar altındaki ifadelerden daha önemli olduğunu ortaya koymaktadır.

Bu grupta "alan çalışması sırasında alanı tanıyan uzman bir öğretim üyesinin bulunması motivasyonumu sağladı (motivasyon etkisi) (,913)" ve "alan çalışması ilgili derse aktif katılım göstermeniz açısından motivasyonumu arttırdı (öğrenme sürecindeki yeri) $(, 913)$ " değişkenleri en büyük ağırlığı alan değişkenlerdir. 1. faktör altında bir diğer yüksek faktör birimleri "alan çalışmasına katılmadan önce yapılan bilgilendirme eğitimi motivasyonumu sağladı (,828) (motivasyon etkisi) "ve "Alan çalışması ilgili derse ait sonuç ürünlerini hazırlarken motivasyonumu arttırdı (,807) (öğrenme sürecindeki yeri)" olmuştur. Eğitime katkı grubu altındaki parametrelerden "yapılan bu alan çalışması derse ait bilginin kalıcı olmasına katkı sağladı (,882)" ve "yapılan bu alan çalışması dersin görsel öğrenme katkı sağladı (,852)" parametresi de 2 . Faktör yükü altında en yüksek sonuçlarını almıştır. 3. Faktör yükü altında en yüksek sonuç ise, "alan gezisinin teknik şartları beklentinizi karşıladı (,872)" ve "alan gezisi yapılan bölgedeki halkın tutumu beklentimi karşıladı $(, 746)$ parametreleri olmuştur (Tablo 3). 
Tarihi ve Kültürel Özellikleri İçeren Bir Çevrede Gerçekleşen Teknik Gezilerin İç Mimarlık Öğrencilerinin Kazanımlarına Etkisi: Trabzon Çaykara Bölgesi Örneği

Tablo 3. Çalışmanın iç mimarlık eğitimine olan katkısını ölçen faktör analizi sonuçları

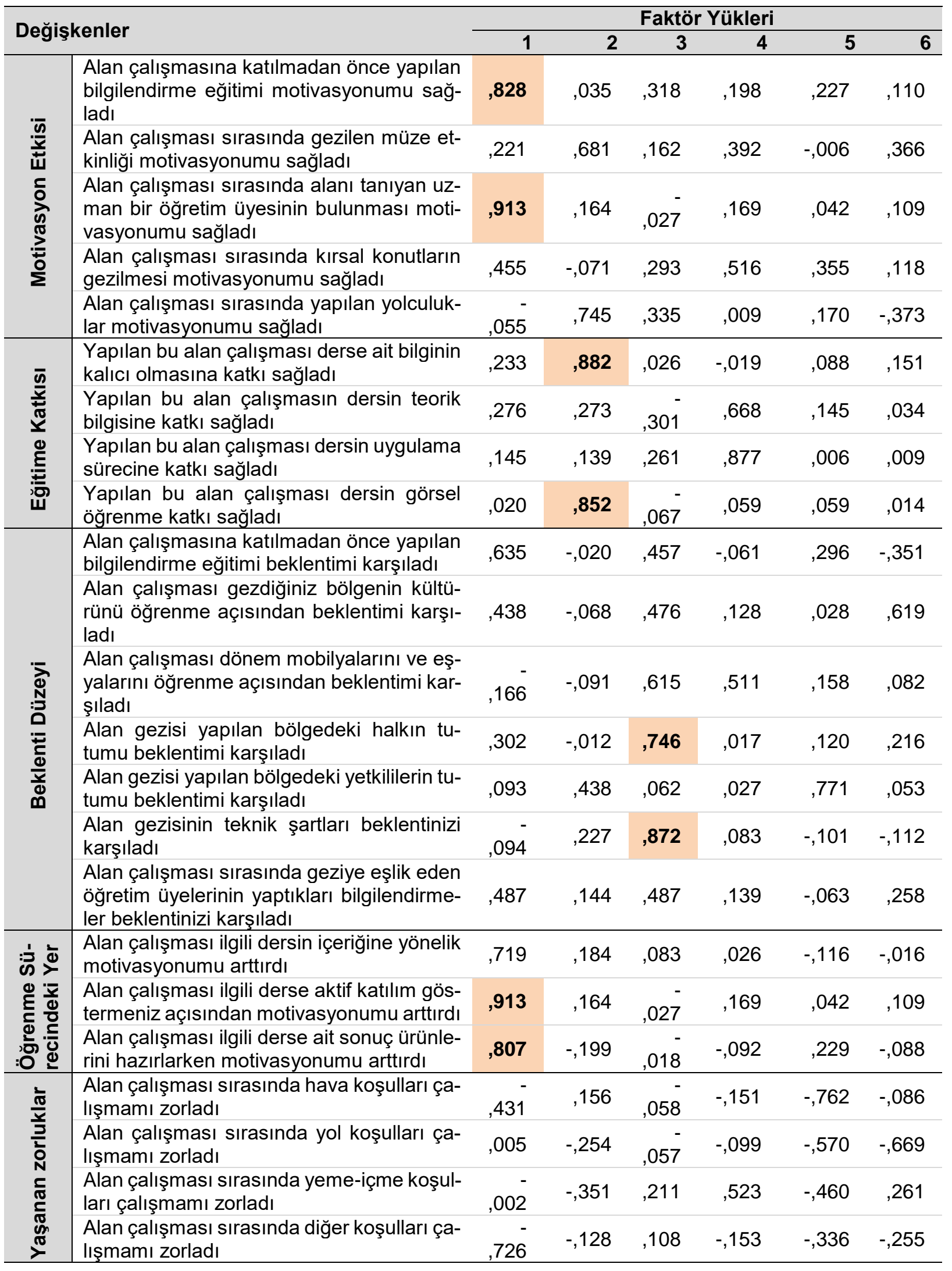


Bu doğrultuda; Tasarım eğitiminde teorik veya uygulama derslerinin birbirlerini destekleyen şekilde biçimlendirilmesi oldukça önemlidir. Yapılan bu uygulama çalışması "derse ait bilginin kalıcı olmasına " ve "dersin görsel öğrenme sürecine" katkı sağlamasında yönlendirici olduğunu göstermiştir. Bu kazanımlar nitelikli bir iç mimarın gelişiminde önemli görülmektedir (Tablo 3).

Uygulama ve teknik gezi çalışmalarında alanı daha önceden bilen ve deneyimleyen bir uzmanın bulunması öğrenciler açısından yararlıdır. Çalışmada alan çalışması öncesinde ve esnasında uzmanlar tarafından yapılan bilgilendirmelerin beklenti düzeyini karşıladığı ve bilginin kalıcı olmasını sağladığı elde edilen sonuçlar arasındadır. Bu sonuca "alan çalışmasına katılmadan önce yapılan bilgilendirme eğitimdeki motivasyonu sağladı" ve "alan çalışması sırasında öğretim üyelerinin yaptıkları bilgilendirmeler beklentileri karşıladı" parametrelerinin diğer parametrelere oranla daha yüksek sonuçlar alması ile varılmıştır (Tablo 3). Özellikle en fazla yük birikimi 1. Faktörde "motivasyona etkisi" başlığında yoğunlaşması; teknik gezilerin iç mimarlık eğitim süreci için gerekliliğini ortaya koymuştur.

Katılımcılara "alan çalışması sonrası tarihi ve kültürel özellikleri içeren bir çevrede daha kapsamlı bir çalışma yapmayı düşünür müsünüz?" sorusu sorulduğunda $\% 80$ "kesinlikle düşünürüm", \%16 "düşünürüm", \%4 ise "bu konuda bir fikrim yok" cevabı alınmıştır (Tablo 4).

Tablo 4. Katılımcıların ilerde tarihi ve kültürel özellikleri içeren bir çevrede araştırma yapma istekleri

\begin{tabular}{lcc}
\hline & \multicolumn{2}{c}{ Katılımcılar } \\
\cline { 2 - 3 } & $\begin{array}{r}\text { Sayı } \\
(\mathbf{N})\end{array}$ & Yüzde (\%) \\
\hline Kesinlikle düşünürüm & 15 & $\mathbf{8 0 , 0}$ \\
\hline Düşünürüm & 4 & 16,0 \\
\hline Fikrim yok & 1 & 4,0 \\
\hline Kesinlikle düşünmem & - & - \\
\hline Düşünmem & - & - \\
\hline Toplam & 25 & 100,0 \\
\hline \multicolumn{2}{l}{} \\
\hline
\end{tabular}

Böylelikle etkinlik öğrencilerin bu gibi çalışmalara karşı ilgisini arttırmış ve başka çalışmalarda yapması için fikir sahibi olmasına yardımcı olmuştur. Çalışmanın öğrenciler üzerinde böyle bir algı ve istek yaratması oldukça önemlidir. Bu sonuç $\% 80$ oranla "alan çalışması sonrası tarihi ve kültürel özellikleri içeren bir çevrede daha kapsamlı bir çalışma yapmayı düşünürüm" cevabı ile desteklenmektedir (Tablo 4).
Katılımcılara "alan çalışması esnasında yaşadığınız zorluklar nelerdir?" sorusuna \%71 oranla "alan çalışması sırasında hava koşulları çalışmamı zorladı" parametresi kesinlikle katılıyorum cevabı almıştır. Diğer sonuçlarda ise "alan çalışması sırasında diğer koşulları çalışmamı zorladı" \%55 (kesinlikle katılıyorum) ve "alan çalışması sırasında yol koşulları çalışmamı zorladı" \%46 (kesinlikle katılıyorum) sonuçları elde edilmiştir (Tablo 5).

Tablo 5. Katıımcıların alan çalışması esnasında yaşadığı zorluklar

\begin{tabular}{|c|c|c|c|c|c|}
\hline & $1^{*}$ & $2^{*}$ & $3^{*}$ & $4^{*}$ & $5^{\star}$ \\
\hline $\begin{array}{l}\text { Alan çalışması sırasında hava koşulları ça- } \\
\text { lışmamı zorladı }\end{array}$ & $\% 71$ & $\% 13$ & $\% 9$ & \%4 & $\% 3$ \\
\hline $\begin{array}{l}\text { Alan çalışması sırasında yol koşulları çalış- } \\
\text { mamı zorladı }\end{array}$ & \%46 & $\% 24$ & $\% 10$ & $\% 7$ & $\% 13$ \\
\hline $\begin{array}{l}\text { Alan çalışması sırasında yeme-içme koşul- } \\
\text { ları çalışmamı zorladı }\end{array}$ & \%31 & \%25 & \%24 & $\% 13$ & $\% 7$ \\
\hline $\begin{array}{l}\text { Alan çalışması sırasında diğer koşulları ça- } \\
\text { Iışmamı zorladı }\end{array}$ & $\% 55$ & $\% 30$ & - & $\% 5$ & $\% 10$ \\
\hline $\begin{array}{l}1^{*}: \text { Kesinlikle katılıyorum } \\
2^{*}: \text { Katılıyorum } \\
3^{*}: \text { Fikrim yok } \\
4^{*}: \text { Katılmıyorum } \\
5^{*}: \text { Kesinlikle katılmıyorum } \\
\mathrm{N} \text { sayısı örneklem hacmini gecmektedir }\end{array}$ & & & & & \\
\hline
\end{tabular}


Bu doğrultuda; Trabzon ilinin yoğun yağmur alan bir il olması ve havanın çoğu zaman anlık değişkenlik göstermesi ile ilişkili olduğu düşünülmektedir. Bu nedenle yapılacak olan bu gibi çalışmalarda ilin iklimsel verileri dikkate alınıp gezi planlamaları yapılmalıdır.

Katılımcıların etkinlikte beklentilerini ve bu etkinliğin eğitime olan katkısı arasındaki ilişkiyi belirlemek için korelasyon analizi yapılmıştır. Sonucunda parametreler arasındaki korelasyon analizi ile ilişki durumları belirlenmiştir. Pearson korelasyon katsayıları \%99 önem düzeyinde hesaplanmıştır (Tablo 6). Analiz sonucunda eğitime katkı parametreleri arasında yer alan "Dersin uygulama sürecine katkı sağladı" ile beklenti düzeyi ölçüm parametrelerinden olan "Alan çalışması dönem mobilyalarını ve eşyalarını öğrenme açısından beklentileri sağladı" parametresi arasında bir korelasyon olduğu görülmüştür $(r=446)$. Beklenti düzeyi ölçüm parametreleri arasında yer alan "alan gezisi yapılan bölgedeki halkın tutumu beklentinizi karşıladı ile "Alan çalışması gezdiğiniz bölgenin tarihi ve kültürel değerlerini öğrenme açısından beklenti sağladı" parametresi arasında korelasyon tespit edilmiştir ( $r=569$ ).En yüksek korelasyon ise "Bilgiyi kalıcı kıldı" ve "Bu alan çalışmasının dersin uygulama sürecine katkı sağladı" parametreleri arasında olduğu tespit edilmiştir ( $r=813)$. Bir diğer yüksek korelasyon sonucu "Alan çalışması dersin teorik bilgisine katkı sağladı" ve "Dersin uygulama sürecine katkı sağladı" parametreleri arasında görülmektedir ( $r=586)$. Sonuçta yapılan bu etkinliğin eğitime katkı sağladığı, beklentileri karşıladığı ve bu iki kategori arasında ilişki olduğunu bizlere göstermekte; özellikle uygulama süreci ile tarihi ve kültürel değerleri öğreniminin yaşayarak (uygulama süreci içinde) deneyimlenmesi gerekliliğinin altını çizmiştir. Tüm verilere ait korelasyon bilgileri Tablo 6'da verilmiştir.

Tablo 6. Etkinlikten beklentilerin ve etkinliğin eğitime katkısı arasındaki ilişkili olduğu parametrelerin korelasyon tablosu

\begin{tabular}{|c|c|c|c|c|c|c|c|c|c|c|}
\hline & A & B & C & D & $E$ & $F$ & $\mathbf{G}$ & H & _ & $\mathbf{J}$ \\
\hline A & 1 & & & & & & & & & \\
\hline B & 210 & 1 & & & & & & & & \\
\hline C & , 143 &, 586 & 1 & & & & & & & \\
\hline D &, $813^{* *}$ &, 210 &, 143 & 1 & & & & & & \\
\hline$E$ & 071 & 115 & ,339 &,- 106 & 1 & & & & & \\
\hline$F$ &,- 052 & 016 &, $446^{*}$ &,- 052 & ,315 & 1 & & & & \\
\hline $\mathbf{G}$ &, 114 & 014 & ,243 &,- 044 &, $569^{\prime \prime}$ & ,384 & 1 & & & \\
\hline $\mathrm{H}$ & $550^{*+}$ & ,232 & , 107 & ,397 &, 144 & , 182 & ,156 & 1 & & \\
\hline I & , 141 & -153 & ,369 & ,141 & ,333 &, $455^{\star}$ &, $539^{* *}$ & 000 & 1 & \\
\hline $\mathbf{J}$ & ,320 & 266 & ,387 & 085 &, $535^{\circ \prime \prime}$ & ,168 &, $544^{* *}$ &, 116 & $401^{*}$ & 1 \\
\hline
\end{tabular}

A- Bilgiyi kalıcı kıldı

Eğitime katkı düzeyi parametreleri

\section{Beklenti düzeyi ölçüm parametreleri}

B- Alan çalışması dersin teorik bilgisine katkı sağladı

C- Dersin uygulama sürecine katkı sağladı

D- Bu alan çalışmasının dersin uygulama sürecine katkı sağladı

E- Alan gezisi yapılan bölgedeki halkın tutumu beklentinizi karşıladı

F- Alan çalışması dönem mobilyalarını ve eşyalarını öğrenme açısından beklentileri sağladı

G- Alan çalışması gezdiğiniz bölgenin tarihi ve kültürel değerlerini öğrenme açısından beklenti sağladı

$\mathrm{H}$ - Alan gezisi yapılan bölgedeki yetkililerin tutumu beklentileri karşıladı

I- Alan gezisi teknik şartları beklentinizi karşıladı

J- Alan çalışması sırasında geziye eşlik eden öğretim üyelerinin yaptıkları bilgilendirmeler beklentileri karşıladı

${ }^{*}(p<0.05),{ }^{* *}(p<0.01)$,

Öğrencilerin etkinliğe karşı beklenti ve bu eğitimin öğrencilere katkısı arasında olumlu bir ilişkinin olduğu çaışma kapsamında elde edilen sonuçlar arasındadır (Tablo 6).

Teknik geziler, öğrencilerin yaratıcılıklarını ve eğitim hayatlarını olumlu etkilediğinden iç mimarlık eğitim prog- ramlarına çeşitlenerek dahil edilmesi ya da mevcut sayısının arttırılması bir gereklilik olmuştur. Çalışkan (2008), teknik gezileri ders programına dahil eden derslerde; öğrencilerin, bilgileri daha kolay içselleştirdiği ve derinleştirildiğini ve sürecin daha eğlenceli olduğu ve motivasyonlarını arttırdığını belirtmiştir. İnformal bir eğitim süreci olarak iki farklı günde gerçekleştirilen çalışma, öğrenci- 
lere kendilerini iyi bir şekilde ifade etmelerine katkı sağlarken; bu bilgilerin kalıcılığını da ortaya koyar (Orion ve Hofstein, 1994; Yürekli ve Yürekli, 2011; Benian ve Mısırlı, 2017). Diğer öğrenme araçlarının çok azı, planlanmış bir gezisinin sağlayacağı öğrenme deneyimini yaşatabilir (Hurley ve Marlane, 2006; Tortop ve Özek, 2013, Bozdoğan ve ark., 2015). Öğrenmeye destek sağlayan, okul dışı alan gezilerinin yapılandırılmış bir deneyim oluşturma yolu olduğu benzer sonuçlar ile farklı disiplinlerdeki çalışmalarla da desteklenmektedir (Bitgood, 1989; Orion ve Hofstein, 1994; DiEnno ve Hilton, 2005; Sebasto ve Cavern, 2006; Farmer ve ark., 2007; Tortop ve Özek, 2013). Bu kapsamda yapılan çalışma, iç mimarlık eğitimine katkısını ortaya koymuş ve öğrencilerin eğitimlerinin daha kaliteli bir seviyeye çıkartmasına yardımcı olma amacıyla alternatif bir süreci aktarmıştır. Böylelikle eğitim sürecinde teknik gezilerin, değerine ve önemine vurgu yapılmıştır.

\section{SONUÇ VE ÖNERILER}

Günümüzde, tasarım temelli birçok disiplinde heyecan verici pek çok eğitim programının uygulanmakta olduğu bir gerçektir. Bunlar içinde teknik gezi gibi etkinlikler; bu eğitim sürecini "amacına" daha çok yaklaştırmaya yardımcı olmaktadır. Aynı şekilde birçok derste yeterli sayıda ve iyi programlanmış teknik gezilerin iç mimarlık eğitimini daha ileri götüreceği düşünülmektedir.

Çalışmanın temel amacına gelince, iç mimarlık eğitiminde mekân ya da alanın deneyiminin önemi ortaya konulmuş ve alan gezilerinin (anlaşılmıyor), dersteki görsel sunumlardan daha etkili bir öğrenme yöntemi olduğu, bakmak ile görmek arasındaki farkın anlaşıldığı ve mobilya, kültür, tarihi çevre gibi konularına ilgiyi arttırdığı tespit edilmiştir. Elde edilen verilerin ışığında gelecekte planlanan geziler için farkındalık oluşturulmak istenmiş ve motivasyonu arttırıcı zorlukları azaltıcı önlemlerin neler olabileceği ortaya konmuştur.

Bu doğrultuda; hem ders saati az olan hem de çoğunlukla teorik konu anlatımını içeren seçmeli dersler de bile, teknik gezilerin yapılmasının, öğrencilerin derse olan ilgilerini arttırarak teorik dersi algılamalarını kolaylaştırdığı da bir diğer veridir. Ayrıca dersin içeriğini oluşturan vernaküler mobilyaların alanda tespiti ve özelliklerinin ortaya konması öğrencilerin kültür varlıklarını yerinde tanıma deneyimi sağlamıştır.

Benzer çalışmalar için aşağıdaki öneriler verilebilir;

- Teknik gezi sürecinin daha önce edinilen deneyimler ışığında programlanması; gezinin veriminin artmasını sağlayabilir, bu nedenle benzer gezilerin yapıldığı ders süreçleri incelenebilir,
- Uygulama sürecinin derslere dahil edilmesine bir vasıta olarak kabul edilen teknik gezilerin; sanat ve tasarım ile yakından ilişkili derslerde de öncelik verilmesi ile öğrencilerin çevre ya da ürünlerle ilişki kurmasını ve yaşayarak öğrenme sürecine katılmasını kolaylaştırabilir,

- Çalışmada seçmeli ders, araştırmanın örnekleminin sayısını etkilemiş olsa da; ileride yapılacak olan diğer çalışmalara da altık oluşturacak niteliktedir. Özellikle benzeri bir çalışma son sınıf iç mimarlık öğrencileriyle de yapılması farklı yarıyıldaki öğrencilerin teknik gezilerden beklentileri arasındaki benzerlikler/farkları kıyaslama imkanı sağlayarak başka bir çalışma konusu olabilir. Böylece iç mimarlık öğrencileri için daha kapsamlı bir çalışmaya zemin hazırlanabilir.

\section{TEŞEKKÜR}

Bu gezi kapsamında Trabzon Büyükşehir ve Çaykara Belediyesine; Köseli köyü muhtarı Hüseyin DíLMAÇ'a; Çambaşı köyü muhtarı Nihat KAPLAN'a; 2018-2019 yılı "Kültür ve Mobilya" dersini alan öğrencilere katkılarından dolayı teşekkür ederiz.

\section{KAYNAKLAR}

Acar, R. (2017). Mardin İl Bölgesinde Okullardaki Sosyal Etkinliklerin (Tiyatro, Müzik, Spor, Dans, Şenlikler) Lise Dönemi Ergen (14-18 Yaş) Kişiliğe Etkileri. Yüksek Lisans Tezi, İstanbul Gelişim Üniversitesi, Sosyal Bilimler Enstitüsü, İstanbul.

Atayeter, Y., Tozkoparan U. (2014). Sosyal Bilgiler Öğretmenleri ve 6. Sınıf Öğrencilerinin Sosyal Bilgiler Dersinde Gezi Gözlem Yönteminin Uygulanmasına Yönelik Görüşleri. Mehmet Akif Ersoy Üniversitesi Eğitim Bilimleri Enstitüsü Dergisi, 3(5): 1-21.

Ballı, A. (2009). 9. Sınıf Fiziki Coğrafya Konuları Öğretiminde Gezi Gözlem Yönteminin Önemi (Bağcılar İlçesi Örneği). Yüksek Lisans Tezi, Marmara Üniversitesi, Eğitim Bilimleri Enstitüsü, İstanbul.

Benian, E., Mısırlı, A. (2017). Mekan Deneyiminin Mimarlık Tarihi Eğitimine Katkısı. Uluslararası Stratejik Araştırmalar Kongresi, 12-15 Ekim, 2017, Antalya, Türkiye, 63p.

Berdi Gökhan, Ç., Atasoy A. (2005). İç Mimarlık Eğitim Programı Tasarımı ve Geliştirme Modeli Önerisi. ITÜ Dergisi Mimarlık Planlama Tasarım, 4(2):25-36.

Ertaş Beşir, Ş. (2020). Kişisel Arşiv.

Bitgood, S., (1989). School Field Trips: An Overview Visitor Behavior. 4(2): 3-6.

Bozdoğan, A. E., Okur, A., Kasap, G. (2015). Planlı Bir Alan Gezisi İçin Örnek Uygulama: Bir Fabrikası Gezisi. Karadeniz Sosyal Bilimler Dergisi, 7(14): 1-12.

Camiz, A. (2014). Urban Morphology and Architectural Design of City Edges and Vertical Connections in Historical Contexts. In Cavallo, R.; Komossa, S.; Marzot, N.; Berghauser Pont, M. \& Kuijper, J. (eds.), New Urban Configurations. Delft University Press-IOS Press, Amsterdam.

Çalışkan, O. (2008). Flüvyal Jeomorfoloji Konularında Gezi Gözlem Metodu ve Değerlendirilmesi. Yüksek Lisans Tezi, Ankara Üniversitesi, Sosyal Bilimler Enstitüsü, Ankara. 
Tarihi ve Kültürel Özellikleri İçeren Bir Çevrede Gerçekleşen Teknik Gezilerin İç Mimarlık Öğrencilerinin Kazanımlarına Etkisi: Trabzon Çaykara Bölgesi Örneği

DiEnno, C.M, Hilton, S.C. (2005). High school students' knowledge, attitudes, and levels of enjoyment of an environmental education unit on nonnative plants. The Journal of Environmental Education. 37(1): 13-25.

Farmer, J., Knapp, D., Benton G.M., (2007). An elementary school environmental education field trip: long-term effects on ecological and environmentalknowledge and attitude development. The Journal of Environmental Education. 38(3): 33-42.

Garipağaoğlu, N. (2001). Gezi-gözlem Metodunun Coğrafya Eğitimi ve Öğretimindeki Yeri. Marmara Coğrafya Dergisi, 3(2):13-30.

Hurley, M. M., (2006). Field trips as cognitive motivators for high level science learning. American Biology Teacher. 68(6):61-66.

Mazman, F. (2007). Sosyal Bilgiler Eğitiminde Gezi Gözlem Metodunun Uygulanmasına İlişkin Bir Araştırma (Tokat Örneği). Basılmamış Yüksek Lisans Tezi, Gaziosmanpaşa Üniversitesi, Sosyal Bilimler Enstitüsü, Tokat.

Orion, N., Hofstein, A., (1994). Factors that influence learning during a scientific field trip in a natural environment. Journal of Research in Science Teaching, 31(10):1097-1119.

Öner, Ü. (2007). İlköğretim 7. Sınıf Sosyal Bilgiler Dersi Tarih Konularının Öğretiminde İşbirlikli Öğrenme Yönteminin Öğrenci Başarısına Etkisi. Yüksek Lisans Tezi, Fırat Üniversitesi, Sosyal Bilimler Enstitüsü, Elazığ.

Sebasto, N.J.S., Cavern, L. (2006). Effects of pre-and posttrip activities associated with a residential environmental education experience at the New Jersey school of conservation students' attitudes toward the environment. Journal of Environmental Education, 37(4): 3-17.

Shih, J., Hwang, G., Chu, Y. (2010). "Development And İnstructional Application of U-Library on Butterfly and Wetland Ecology for Context-Aware Ubiquitous Learning." IJMLO, 4: 253-268.

Sırtkaya Uzun, A., Ertaş Beşir, Ş. (2019). İnformal Eğitim Alanı Olarak Bilim Merkezlerinin İç Mekan Kurgusu. Karadeniz 2. Uluslararası Sosyal Bilimler Kongresi, 23-25 Ağustos, 2019, Rize, Türkiye, 199-216p.

Sünbül, A. M. (2011). Öğretim İlke ve Yöntemleri. Eğitim Yayınevi, Ankara.

Tortop, H., Özek, N., (2013). Proje Tabanlı Öğrenmede Anlamlı Alan Gezisi; Güneş Enerjisi ve Kullanım Alanları Konusu. Hacettepe Üniversitesi Eğitim Fakültesi Dergisi, 44(44): 300-307.

URL-1 (2019). http://www.caykaragundem.com/haber/cambasi-mahallesi-5198.html (Erişim Tarihi: 28.05.2019).

URL-2 (2019). http://www.caykaragazetesi.com/mahalleler/koseli-koyu-mahallesi-10806/ (Erişim Tarihi: 28.05.2019).

Yürekli, İ., Yürekli, H. (2011) Mimari Tasarım Eğitiminde Enformellik. ITÜ Dergisi, 3(1): 101-122.

Yazıcı, N. (2013). Lise Müfredat Programlarında ve Ders Kitaplarında Çanakkale Savaşı'nın Öğretimi Üzerine Eleştirel Bir Yaklaşım. Hacettepe Üniversitesi Eğitim Fakültesi Dergisi, (28)2: 535-550. 